Social Sciences on Contemporary Turkey

EU-Turkey: Sociological Approaches

\title{
Turkish Trade Unions and the European
}

Boomerang

\section{Zeynep Alemdar}

\section{(2) OpenEdition \\ 1 Journals}

\section{Electronic version}

URL: http://journals.openedition.org/ejts/3774

DOI: $10.4000 /$ ejts.3774

ISSN: $1773-0546$

Publisher

EJTS

\section{Electronic reference}

Zeynep Alemdar, «Turkish Trade Unions and the European Boomerang », European Journal of Turkish Studies [Online], 9 | 2009, Online since 24 March 2015, connection on 16 February 2020. URL : http:// journals.openedition.org/ejts/3774 ; DOI : 10.4000/ejts.3774

This text was automatically generated on 16 February 2020

(c) Some rights reserved / Creative Commons license 


\title{
Turkish Trade Unions and the European Boomerang
}

\author{
Zeynep Alemdar
}

The well-known literature on the transnational linkages between domestic actors and international organizations argues that domestic groups that are repressed by their states would seek international allies to help them affect their states' policies in favor of their own agenda. Keck and Sikkink's (1998) 'boomerang effect' and Risse-Kappen, Ropp and Sikkink's (1999) 'spiral model' explain this process wherein domestic NGOs reach out to and lobby international allies who then put pressure on the repressive state, which in turn transforms its policy towards the domestic actors. Through their interactions with international allies, domestic actors thus contribute to the socialization of their states as a 'member of the international community in good standing' (Risse-Kappen 1999: 530).

Both the boomerang and the spiral models explain the level of interconnectedness between domestic and international politics, and trace a framework that helps us study the transnational interactions between different actors in all their complexity. These models aim to provide a framework for comparison. However, their explanations of domestic actor behaviors, while understandable and useful for generalization, prevent us from understanding the changing dynamics of relations between domestic actors, international organizations, and the state.

Both models employ a 'weak/strong' dichotomy to explain the domestic actors' position within the national realm and classify states in two groups, repressive and democratic. This study argues that we need to go beyond these dichotomist assumptions in order to better understand the nature of these relations. Domestic actors within limited political opportunity structures would rationally seek international support to strengthen their own policy positions and garner support for the realization of their aims, but this process and the environment in which they function cannot be taken as static, since national and international developments and their interrelationships affect internal environment, influencing the actors' behaviors and their interest and preference formations. Domestic actors' interactions with their 
'international allies' depend on how they perceive the international ally. Therefore, this research postulates that first, the more domestic organization sees the international organization's issues as salient to itself, the more likely it is to appeal to the latter. Second, defining domestic actors as weak since they have limited political opportunities is necessary yet not a sufficient explanation of domestic actors' position within the national realm. One has to understand to what extent this limitation works and when can the domestic actors resort to international allies. It will be impossible for a domestic organization with no access or no legal right to appeal to an international ally. Thus, understanding the different levels of closeness is important. This paper argues that, despite the literature's claims that the closed environments are more likely to induce domestic actors to resort to the international arena, domestic organization appeal to international organization depends on the liberalization level of the domestic environment.

This research investigates the interactions between Turkish trade unions and the European Union, which, according to the boomerang and spiral models, should be an excellent case in point. In the Turkish case, given that the Turkish foreign policy goal of full membership to the EU is more than six decades old, and the EU strongly emphasizes the need for more democratic rules and norms for the candidate states, one would say that the EU would be the perfect leverage tool for those domestic organizations. The Europeanization literature posits that domestic actors gain new resources during the EU membership processes, and this process brings about a redistribution of power among the domestic actors (Risse, Green-Cowles \& Caporaso 2001: 11). It is thus expected that domestic actors use Europeanization as an opportunity to further their goals.

5 Further, since the Turkish-EU relations has a long history that covers the whole period of EU's enlargements and 'deepening', as well as Turkey's tumultuous political history of three (and a half) military- coups, and an important number of government changes, this case can account for the time dimension mired in the hypotheses above.

6 Through structured-focused interviews with trade unionists, EU and Turkish government officials, primary, secondary and archival data, research on Turkish trade unions' interactions with the EU shows that labor organizations' use of the EU as leverage tool depends mostly on the domestic organization's specifics. Although the literature expects them to appeal to the EU for better labor standards or workers' rights Turkish domestic actors' use of the EU depends heavily on the domestic environment and their respective EU perceptions.

7 This article thus focuses on the domestic factors that affect the boomerang and spiral models' success or failure in explaining the domestic actors' appeal to international organizations. It explains the reasons why, contrary to the expectations of the well known literature, Turkish domestic organizations do not appeal to the EU as often as expected, and why they do not use the EU discourse effectively to change state policies.

8 Doing so provides us with important insights that improve our understanding of domestic organizations' interactions with their states and international organizations. What are the reasons behind a domestic actors' appeal to an international organization? What are the particularities of employee groups studied here that can inform us about other domestic groups, and for similar groups in different countries?

The paper first presents a brief survey of the transnational literature that explains the interactions between domestic groups and international organizations. It then focuses 
on how the literature's expectations concerning the reasons why domestic organizations appeal to international organizations are not completely met in the Turkish case. In the conclusion, the paper raises some questions that contribute to our understanding of domestic-international organization interactions.

\section{Transnational Literature: Boomerangs and Spirals}

10 The transnational literature on advocacy networks argues that these organizations appeal to international organizations (IOs) in order to alter the behaviors of their states. In their boomerang model, Keck and Sikkink (1998: 12-13) assess:

\footnotetext{
...domestic NGOs bypass their state and directly seek out international allies to try to bring pressure on their states from outside. This is most obviously the case in human rights....On other issues...[NGOs'] international contacts can amplify the demands of domestic groups, pry open space for new issues, and then echo back these demands into the domestic arena.
}

11 The spiral model, a more developed version of the boomerang model, explains the complex interplay between the external mobilization, the target state's policy choices, and domestic opposition against repression. The spiral model explains a five-stage process. First, activists take the issue to the international realm, disseminating information about the human rights violations and lobbying the Western states and IOs to pressure the state. The repressive state dismisses the complaints as unjustified. Advocacy networks go on to prove and justify their case, pointing out the state's intentional violation of internationally recognized moral standards. The Western states or the IOs put more pressure on the repressive government, which cannot insist on denial, partly because of their need and desire to be a 'civilized state', and a member of the international community in good standing (Risse 1999: 530). The level of state repression declines and opposition groups, which were previously deterred, mobilize. The target state under pressure from both above and below not only stops repression but is forced to set up domestic institutions to implement international normative standards (Hasenclever 2005: 64).

Both models stress that domestic actors use transnational networks since they are suppressed in their own societies. They argue those domestic actors who have limited or no recourse within domestic political or judicial arenas interact with IOs. Risse (2002: 267) finds also that transnational activities of human rights groups are particularly effective in inducing policy change when 'domestic groups in the repressive state are too weak or too oppressed to constitute a serious challenge to the regime'. Transnationalist scholars thus posit that domestic actors, who do not possess the nationally institutionalized mechanisms to have a say in their state's policies, are more likely to prefer to take the issue to the international level. Weak domestic actors see an advantage in turning to the international organizations since IOs can be more powerful in terms of inducing changes in state behavior. They do omit, however, that domestic actors' interaction with an international ally is also usually at the hands of state officials who control the domestic actors. If for example, domestic actors are in jail, are denied passports, or are forbidden to have interactions with "foreigners" then how are they going to interact with an international ally, let alone use the ally as a legitimate 'stick' against the government? The paper thus tries to refine this hypothesis arguing 
that an environment's closeness should be better explained- using the term liberalization of the domestic environment. insufficient to explain the reasons for the domestic organizations' appeal or to elaborate the reasons for their effectiveness. The 'repressive-oppressive state' variable limits research on domestic-international organization interaction to underdeveloped countries, or authoritarian states, and to specific time periods, thereby neglecting the evolution of a state-regime over time. ${ }^{1}$ Introducing the time dimension to research, however, gives us the ability to move with the reality of dynamic factors (Heclo 1972, 93).

\section{The Turkish Case} their relations with the EU since Turkey's first application to the EU's predecessor, the EC, in 1959 until 2005. It traces Turkey's political scene from the 1960s' more open domestic context to 1980s' military rule and to the post-1999 EU process. Within this period, especially after the 1980 military coup, Turkish trade unions have been particularly repressed. Since their rights are better protected in the EU system, and given that Turkey's will for EU membership is solid (despite some disruptions between the parties and the Turkish foreign policy establishment's internal conflicts during the early years), it is expected that these groups would appeal to the EU in order to change state policies. Findings suggest, however, that these organizations' appeal to the EU is highly dependent on the domestic context. They do appeal to the EU, but their appeal is highly dependent on their organizational traits, and they can actually use the EU in a negative way, expressing opposition to EU membership in order to appeal to their constituents.

In order to apply the boomerang and spiral models to the Turkish case properly, and to compare the organizations' relations with the EU, this paper draws a framework for these organizations' appeals to the EU based on Keck and Sikkink's (1998) model. Keck and Sikkink (1998: 25) summarize the goals of transnational activists under five categories: to get an issue on the international agenda, to get actors to change their discursive positions, to change institutional processes, to influence policy change, and to influence actor behavior. Based on their framework, this paper argues that domestic groups may appeal to international organizations in three ways. First, they can use the IO in their discourse to raise public awareness for issues that they are interested in and to attempt to convince both government officials and the general public to support their own policy positions. Second, domestic groups can lobby the IOs to put pressure on the state. By mobilizing outside pressure, they can strengthen their own lobbying activities directed towards the state. Third, they can even use this to become more influential players in decision-making processes that are of interest to them. The appeal to IOs can thus be grouped under three broad headings: agenda-setting, lobbying to push for policy change, and changing institutional procedures.

When the organization mentions the EU when calling upon the government to make a change in its policy at a press conference or through a press release or other publication, this act is categorized as agenda-setting. When a member of the organization presents the organization's views directly to state officials, then the 
appeal is in the form of lobbying. When a representative of the organization voices his views in a decision/ policy making institution, then it is appealing to the EU within institutional procedures and thus influencing these procedures.

The paper looks at Confederation of Turkish Trade Unions [Türkiye Isş̧i Sendikaları Konfederasyonu, TÜRK-İş], Confederation of Revolutionary Trade Unions [Türkiye Devrimci İşçi Sendikaları Konfederasyonu, DISK], and Confederation of Justice Seekers' Trade Unions (HAK-İs). The research makes use of structured in-depth interviews with civil society representatives, government and EU officials, as well as with scholars who work with or specialized in Turkish civil society. The paper also uses primary sources on the historical background and the more recent activities of civil society organizations in Turkey. Interviewees have supplied numerous folders, brochures and documents about their own organizations and sometimes even fax messages that they have exchanged with other officials. There is also an emerging literature on civil society in Turkey. The Economic and Social History Foundation of Turkey publishes the proceedings, discussions and conclusions of civil society symposia that it initiated in December 1994 in a series of books. Different Civil Society Organizations (CSOs) such as the Third Sector Foundation and the Civil Society Development Center prepare reports and working papers on associational life in Turkey.

\section{Turkey's Domestic Environment and the EU}

Becoming a member of the European Union has been a fundamental issue in Turkish politics and daily life for more than four decades. In 1963 when Turkey and the European Community signed the Association Agreement (Ankara Treaty), Turks saw this as an opportunity to enter the gates of Europe; Europe symbolized the Western civilization that was to be attained according to the Turkish modernization project. Despite the ruptures, interruptions, and fluctuations in the Turkish-EU relationship over the years, the EU has been seen as the international force that catalyzes Turkey's march towards the West and towards modernity, which, in Turkish political jargon, seem to be equal to democratization.

The EU's role as a vehicle for the democratization of Turkey has been widely discussed. Since 1987, the Turkish state's attempts to liberalize the domestic environment, severely closed due to the 1980 military coup, have mostly coincided with European demands. Turkish governments have passed nine major political reform packages that provided for a considerable opening up of the Turkish political environment since the Helsinki Summit, in which the EU announced Turkey as a candidate for membership. In 2005, accession negotiations that serve to harmonize Turkish laws with European laws started. Thus, if we were going to agree with the transnationalist literature's argument that repressed domestic groups tend to search for an international ally who could put pressure on the state, the EU would appear to be the ideal such ally.

In case of the trade unions, after the 1980 coup all but one trade union confederations were disbanded and their leaders were taken into custody. Additional restrictions on freedom of speech, right to assembly and demonstration, and methods of financing limited the employee organizations in every aspect of their activities. Despite the criticisms of the EU's social policy, it is clear that European provisions for trade unions and workers' rights are far better than the Turkish ones. It therefore seems logical to suggest that as soon as the domestic organizations could find ways to interact with 
international organizations when not restricted by law, they would have used the EU as leverage against the Turkish state.

\section{Trade Union Confederations in Turkey}

21 Arguing that increased liberalization of the domestic environment is important in domestic actors' interaction with international organizations, and the more domestic organization sees the international organization's issues as salient to itself, the more likely it is to appeal to the latter, the paper traces the trade unions' interaction with the EU. Employee organizations in Turkey include three confederations of trade unions, Confederation of Turkish Trade Unions [Türkiye Isşçi Sendikaları Konfederasyonu, TÜRKİş], Confederation of Revolutionary Trade Unions [Türkiye Devrimci İşçi Sendikaları Konfederasyonu, DİSK], and Confederation of Justice Seekers' Trade Unions (HAK-İş), bringing together a total of 56 unions, representing 61 percent of the unionized workforce in Turkey. TÜRK-İş is the oldest and the largest confederation, and it is known to be close to the centrist parties in the governments. DISK is the trade union confederation of the left. HAK-İş, emerging from an Islamist background, defines itself with its commitment to 'moral values and justice' which interjects a conservative character to the confederation. It has close relationships with the Justice and Development Party (AKP), which holds the majority in the parliament since 2002 and comes from the same Islamist traditions. Table 1 presents a comparison of these three organizations.

Table 1. Comparison of Employee Organizations

\begin{tabular}{|c|c|c|c|}
\hline & $\begin{array}{l}\text { Confederation of } \\
\text { Turkish Trade Unions } \\
\text { (TÜRK-İş) }\end{array}$ & $\begin{array}{lr}\text { Confederation } & \text { of } \\
\text { Revolutionary } & \text { Trade } \\
\text { Unions } & \\
\text { (DisK) } & \end{array}$ & $\begin{array}{l}\text { Confederation of Justice- } \\
\text { Seekers' Trade Unions } \\
\text { (HAK- İş) }\end{array}$ \\
\hline Goal & $\begin{array}{l}\text { To solve the nation's } \\
\text { workers' problems in } \\
\text { cooperation with but } \\
\text { independent from the } \\
\text { government }\end{array}$ & $\begin{array}{l}\text { To promote the social and } \\
\text { democratic rights of the } \\
\text { working class independently } \\
\text { from political parties, } \\
\text { owners of capital and the } \\
\text { state }\end{array}$ & $\begin{array}{l}\text { To value humanism, } \\
\text { localism, nationalism, } \\
\text { moral values, law and } \\
\text { justice while promoting } \\
\text { the rights of workers }\end{array}$ \\
\hline Type & $\begin{array}{l}\text { Confederation of trade } \\
\text { unions }\end{array}$ & $\begin{array}{l}\text { Confederation of labor } \\
\text { unions }\end{array}$ & $\begin{array}{l}\text { Confederation of trade } \\
\text { unions }\end{array}$ \\
\hline Membership & Voluntary & Voluntary & Voluntary \\
\hline Size* & 35 national unions & 22 national unions & 9 national unions \\
\hline $\begin{array}{l}\text { Financial } \\
\text { Resources }\end{array}$ & Membership dues & $\begin{array}{l}\text { Membership dues, project- } \\
\text { based EU funding }\end{array}$ & $\begin{array}{l}\text { Membership dues, } \\
\text { project-based EU funding }\end{array}$ \\
\hline
\end{tabular}




\begin{tabular}{|c|c|c|c|}
\hline Network & $\begin{array}{l}\text { European Trade Union } \\
\text { Confederations (ETUC), } \\
\text { The EU-Turkey Joint } \\
\text { Consultative Economic } \\
\text { and Social Committee**, } \\
\text { The Economic and Social } \\
\text { Council }\end{array}$ & $\begin{array}{l}\text { ETUC, } \\
\text { permanent representation in } \\
\text { Brussels, } \\
\text { The EU-Turkey Joint } \\
\text { Consultative Economic and } \\
\text { Social Committee, The } \\
\text { Economic and Social Council }\end{array}$ & $\begin{array}{l}\text { ETUC, The EU-Turkey } \\
\text { Joint Consultative } \\
\text { Economic and Social } \\
\text { Committee, The Economic } \\
\text { and Social Council }\end{array}$ \\
\hline
\end{tabular}

* The confederations' sizes proved to be a problematic issue since the statistics are based on the numbers that the trade unions provide. It is the conventional understanding that confederations inflate the number of their members, thus the table includes the number of trade unions belonging to each confederation.

** This Committee serves to facilitate the involvement of the economic and social partners (the employers and employees associations as well as public professional organizations) in the process of consolidating the Turkish- EU relations.

TÜRK-İs was founded in 1952, as a part of the corporatist structure supported by the ruling parties of the time (Tokol 1994: 34). When the 1961 Constitution granted all workers the right to form unions, and recognized their right to collective bargaining and strikes, TÜRK-İş was granted a representational monopoly at the national level, undermining its rivals even in those areas where the latter had already organized the greatest number of workers (Sakallığlu 1991: 57). The state affected the selection of TÜRK-Iş̧ leaders as well, thereby intervening in the confederation's internal governance.

DISK was the main rival to TÜRK-İş during the late 1960s and 1970s. DiSK's socialist representatives criticized TÜRK-İş for its loyalty to governments, and for adopting 'American' style collective bargaining. The third confederation, HAK-iş, was not a major player in Turkish politics until the 1990s.

The 1982 Constitution that the military government enacted restricted the activities of trade unions as with all other types of civil society. Because of their linkages with the radically politicized groups that created the violence of late 1970s, all trade union confederations except TÜRK-İş were shut down. DİSK suffered from the military measures most. Given that it was a strong political force on the left of the political spectrum during the 1970s, the military government dismantled the confederation, and subjected DiSK representatives to trial on the grounds that they attempted to demolish the constitutional regime. Furthermore, the Constitution banned the trade unions (and their confederations) from political involvement.

The new laws stipulated that unions 'shall not pursue political cause, engage in political activity, receive support from political parties or give support to them; nor shall take joint actions with associations, public professional organizations and foundations to promote such aims' (Özbudun 1991: 61). Apart from de-politicizing the trade unions, the new Constitution gave the right to unionize only to workers, restricted the right to strike, introduced a system of inspection for the activities of trade unions and founded a bureaucratic establishment, The Supreme Board of Arbitration, which supervised industrial relations and usurped the political bargaining power of trade unions.

One more blow to unions' bargaining power came with the setting up of the State Collective Agreement Coordination Committee, later reconstituted into the Public Employers Association affiliated with the Turkish Confederation of Employers 
Association (TISK). TÜRK-İş representatives claimed that the foundation of this association only strengthened the government's hold on industry-labor relations since all of its members were public employees. In 1985, the government made a decision to hire public sector employees on contract, which made public employee unionism ineffective (Sakallığlu 1991: 62). These legal modifications led to the political exclusion of organized working class (Barkey 1990: 189).

Although during the 1990s changes to the 1982 Constitution have eased some of the restrictions on the working class, labor's exclusion from Turkish politics still continues. The 1991 elections brought a new coalition government, consisting of the True Path Party (DYP) and the Social Democratic People's Party (SHP), into power. Both parties stressed labor's problems in their programs and promised that syndical rights would be elevated to the International Labor Organization's (ILO) standards. In the meantime the Turkish Criminal Code, under which the trade unions were closed down and banned, was changed and DisK, the second largest trade union confederation, was reinstated after a decade. After many strikes and attempts at entering into a dialogue with the government, organized labor managed to found the first public sector employees' union in 1990 by benefiting from a lacuna in the Constitution which does not specifically ban public sector employees from forming unions (Toprak 1996: 97). In 1992, some unions of public sector employees came together and founded the Turkish Public Employees' Unions Confederation (KAMU-SEN) and in 1995, the second confederation of public sector employees unions, Public Laborers' Unions Confederation (KESK), was founded. ${ }^{2}$

In the meantime, in 1994 Turkey's fragile economy broke down. Supported by the IMF, the government introduced the April 1994 stabilization package that envisaged a radical expenditure cut, and a privatization program for the State Owned Enterprises (SOE). The privatization of State Owned Enterprises threatened organized labor directly since the majority of the workers belonging to trade unions worked in these enterprises.

In addition to the remaining legal restrictions and the privatization program, diversification of the economy during the 1980s and 1990s affected Turkish labor. The heavy industrial sector, which held organized labor together, lost its priority in the economy. Workers in other sectors did not necessarily belong to unions. The number of part-time workers, contractual workers, and service sector workers increased. Most of these workers neither paid taxes, nor had social security pensions (Aydın 2004: 28).

These changes necessitated a reevaluation of the trade union movement. The three big trade union confederations started to change their once hostile positions towards each other and started to cooperate on issues related to workers' rights. For the first time in 1992, the big three confederations celebrated the May $1^{\text {st }}$ Workers' Day together. Their cooperation spread to other areas and the three confederations developed the 'Democracy Platform' in 1993, which later turned into the 'Labor Platform'. These Platforms were attempts at uniting different parts of the civil society (trade union confederations as well as some professional organizations) in order to put an end to the political exclusion that all types of civil society associations had suffered since 1980 .

While the confederations cooperated on the general idea of freedom of labor, they had diverse views on the issue of EU membership. The issue of EU membership, with its influence on the psyche of the Turkish public in 1990s because of the unstable relations 
and never-ending disputes over Turkey's identity, provided the confederations with a subject around which they could frame their own identity.

In the meantime the Turkish government, in its efforts at fulfilling the Copenhagen criteria and adopting the acquis of the EU, started working towards bringing the Turkish laws and practices in labor issues in line with the EU. Turkish governments have been adopting some of the acquis and working on improving the social dialogue. The Economic and Social Council, which brings together the trade union confederations, employer organizations and government officials for consultation on economic and social policies, was founded in 1995. In 1996, the EU-Turkey Joint Consultative Committee was launched. This Committee serves to facilitate the involvement of the economic and social partners (the employers and employees associations as well as public professional organizations) in the process of consolidating Turkish- EU relations. Despite these, Turkey has been lacking in the area of improving social rights as well as adopting the acquis related to social policy. The European Commission's evaluation reports point out that significant constraints remain on the right to organize and the right to collective bargaining and conclude that Turkey still falls short of ILO and EU standards.

The EU's criticisms of Turkish laws and practices ought to logically lead Turkish labor groups to renew their efforts for policy change. With the resources and the ability to pressure the government, the confederations could use the EU as a tool to further their interests. The empirical evidence on Turkish trade unions confederations, however, points to different patterns. Two out of three trade union confederations studied here do not use the EU appeal as an instrument to push for better workers' rights. Instead, they use the EU to further their own organizational interests. What are the reasons?

\section{Confederation of Turkish Trade Unions (TÜRK-iş) and Its Relations with the Turkish Government}

The Confederation of Turkish Trade Unions (TÜRK-İş) is the largest and oldest confederation of trade unions in Turkey. Thus, its relations with the government and its stance towards the EU are illustrative of the state of labor representation in Turkey as well as Turkish perceptions of EU relations. Over the course of TÜRK-İş's history, we see the inability of a labor movement to further its interests. While some blame this on the organizations' cooperative relations with the state since its inception, most tradeunionists argue that it is the discrepancy of interest between the members and the ruling-elite of the confederation. Looking at the interaction of TÜRK-İş with the EU which pushes for better labor standards, we can agree with the latter view at large although it needs refinement. TÜRK-İş appeals to the EU, negatively or positively, for the specific interests of the organization rather than the rights of the workers as a whole. This proves the hypothesis that the domestic actors' interactions with their international allies depend on how they perceive the latter. The more the confederation sees the EU policies in line with its own policies, the more likely it is to appeal to it. The second hypothesis, that liberalization of the environment is important for the organization to establish and pursue relations with the international allies, and use them as enforcers of their own position vis-à-vis their own state, is also proved by the TÜRK-İş case as explained below. Yet, since TÜRK-İş was the least affected among the trade unions (in terms of legal restrictions) following the 1980 coup, other organizations' positions would be more important for this hypothesis. The following 
section describes and evaluates how TÜRK-İş appeals to the EU in its agenda-setting, and lobbying activities and how, via $\mathrm{EU}$, it tries to change the institutional procedures in Turkey.

TÜRK-İş brings together 35 trade unions and claims to have 1,179,983 members, whereas insiders argue that a more accurate number of members is around 900,000 (Aker 2004). TÜRK-İş is financed by its membership fees which are taken directly out of the workers' pay checks (Tiraş 2004).

TÜRK-Iş is the oldest confederation and since its foundation it has kept cooperative relations with the government. An ex-official in TÜRK-İş explains, 'Trade unions were founded when there was not any private sector in Turkey. So, TÜRK-İs had to work with the government' (Aker, 2004). TÜRK-İs, declaring its commitment to stay out of daily politics, is 'beyond party politics.' This motto, according to some, actually hurt the workers' movement in Turkey since TÜRK-İş's non-political stance was not attractive to all trade unions. The subsequent fragmentation and polarization of new confederations, some trade unionists argue, reduced the strength of the workers' movement as a whole and gave way to the perception that labor was actually responsible for market distortions and for the inflation that had been ravaging the country's economy (Sakallığlu 1991: 59-60).

The military government that came to power with the 1980 coup closed down the three confederations that spawned from TÜRK-İs as well as some members of TÜRK-İş and some other independent trade unions. TÜRK-İs as a confederation, however, supported the coup and maintained a 'policy of dialogue' with the government, hoping that once the military rule was over, the restrictions on the unions would be lifted. Contrary to TÜRK-Iss's hopes, the civilian government of the Motherland Party (ANAP) not only kept the restrictions of the military rule but also introduced further limitations such as recruiting public sector employees on contract instead of granting them the right of collective bargaining.

In addition to the Motherland Party's (ANAP) dismissal of TÜRK-İş's demands for over six years, a drastic decline in the purchasing power of the workers and an unequal distribution of income spurred a new round of activism in the trade union movement at the end of the 1980s (Sakallıoğlu 1991: 66-67). By late 1986, TÜRK-İş started to turn against the government. It withdrew its support from the ruling party ANAP, and called the workers to go on strike, using a 'weapon' whose effectiveness TÜRK-İş had questioned since 1982 (Sakallıoglu 1991: 63). In 1987, the number of strikes skyrocketed, from a total number of 21 strikes in 1985 and 1986 to 307 in 1987 (Tokol 1994: 127). Not all of these strikes were organized by TÜRK-İş alone, but the Confederation supported the strikes launched by other confederations and by independent unions.

In 1988, the number of strikes in the private sector decreased, while the public sector employees adopted new forms of 'resistance' protesting the state's wage policies and the prohibition against strikes. These new forms of resistance involved slowing down the work, not working over-time, growing beards and the like (Sakallığlu 1991: 68). Some amendments to the Labor Law were introduced and some of the restrictions on labor unionism were lifted. The actual changes on the law were minimal, but they came at a time when there was a general wave of loosening of the Constitution that the military rule had imposed on the country. 
In 1990 and 1991 trade unions kept on protesting government policies and nation-wide boycotts were held. TÜRK-İş, with the support of HAK-İs, called for a nation-wide daily strike on January 3, 1991. A day later, 48,000 mine workers, who were unionized under MADEN- İş, an affiliate to TÜRK-İs, started to walk from Zonguldak, northwestern Turkey, to the capital Ankara to 'claim their right to workplace safety and collective bargaining.' The 'Grand March to Ankara' was stopped by the government on the grounds that the Gulf crisis had erupted and, at times of national security threats, strikes should be postponed. Collective bargaining took place within the Supreme Arbitration Board in 1992. The same year, TÜRK-İş went through a major change in its management. The new President, Bayram Meral, increased the tone of criticisms against the state's privatization practices.

41 TÜRK-İş organizes public sector employees. Privatization of this sector would cut subsidies of the government and turn the state-owned enterprises to private capitalists. TÜRK-İs clearly announced its desire for government control of the public sector in its declaration of principles in 1995:

'The state should guide national economic development via democratic planning. The state should actively intervene in the market, prioritizing the interests of the country and the people. The state should not leave the market to the hands of the national and foreign monopolies and should impede big companies from cooperating with each other to manage the market (Article 26)... On pricing the products that are produced in the public sector (in the State Owned Enterprises), the principles of a "Social State" should be applied. Subventions, subsidies and support-buyouts are the only ways in which the State can diminish the injustice in the distribution of income (Article 58)' (TÜRK-İş history).

TÜRK-Iş's opposition to the state's privatization policies is explained in Article 39 of the same document:

'State-owned enterprises (SOEs) constitute a primary pillar of the Turkish Republic's economic and political independence. These enterprises should not be sold to local or foreign people or institutions within the framework of privatization. Privatization is only a tool to de-unionize workers and enslave them... The SOEs that were founded to benefit some, under different governments and with inappropriate technologies, should be closed or sold upon consultation with a democratic Economic and Social Council; the workers who serve in these institutions should be placed into other public enterprises. Decisions on privatization should not be taken solely on the basis of the economic profitability of the enterprise but also on the basis of its profitability to the local economy and the local life there' (TÜRK-İş history).

43 TÜRK-İş rigorously opposed the privatization efforts of the government. The Confederation, arguing that the privatization policies are imposed by international organizations, mainly the IMF and the EU, thus opposes these organizations and their policies as they apply to Turkey.

\section{International Linkages, Relations with the EU}

TÜRK-Iş is a member of the International Confederation of Free Trade Unions (ICFTU) and of the European Trade Unions Confederation (ETUC). In the turbulent years of the mid-1950s when the new DP government was trying to establish a liberal economy, the government was not supportive of TÜRK-İş's demand to become a member of the 
international labor union organization, the ICFTU. After the 'liberal' coup of 1960 and its noninterventionist 1961 Constitution, however, TÜRK-İş joined the ICFTU.

At the time of Turkish application for associate membership to the EC, TÜRK-İş supported the government's policy. The confederation was already a member of the ICFTU under its European regional group, and with the formation of the European Trade Unions Confederation (ETUC) in 1973, it became a member of the ETUC. Thus, by the early 1970s, TÜRK-İş was a regular member of the international trade union community.

The fragmentation and radicalization of the labor movement in the 1970s and the tightening of state control on labor movements with the 1980 military coup, however, hurt Turkish organized labor's position in the international arena. TÜRK-İş's support for the 1980 coup stirred international criticism, and its membership in the European confederation, the ETUC, was suspended. A former TÜRK-İş representative explains, 'In 1980, the ETUC was opposed to the Turkish government in power [military government]. Because TÜRK-İş's secretary general was a minister in that government, our membership was suspended' (Aker 2004). Aker (2004) further explains the reasons for the breakdown of the relationships,

'During the foundation of the ETUC, which was actually spun out of the ICFTU, we were already a member of the European bloc. Europe was not interested in us though. We were always the "outsiders." Our areas of interest and technical problems did not overlap with that of the ETUC. For example when they were discussing the Single Market and its effects on European labor during 1980s, we were trying to figure out who we were, what we should do.'

Although TÜRK-İş could not reach any common ground with the ETUC until the late 1980s, the organization's relations with the ILO were intact. In 1995, Turkey ratified the ILO Termination of Employment Convention (C158), which standardizes the firing process. The ratification of this agreement permitted ILO surveillance of Turkish employment practices. Upon TÜRK-İş's two complaints to the ILO, in 1996 and in 2000, the ILO warned the Turkish government that it must change its internal legal practices (Çelik 2003). In 2000, the Ministry of Labor and Social Security started to work on the law on work safety and stated in the National Program (presented to the EU) that passing that law was a short-term priority (Çelik 2003).

Despite the government's attempts to improve its policy, TÜRK-İş was not satisfied. The confederation started to take an openly anti-EU position after 2000, for a variety of reasons related to the organization's own structure. Only recently, since the EU's December 2004 decision to start membership negotiations with the Turkish government in October 2005, has TÜRK-İş softened its criticisms against the EU and Turkey's EU membership. Several explanations for the anti-EU stance of the confederation may be advanced.

First, as an organization whose strength is determined by the number of its members and financed by membership fees, TÜRK-İs has to take a stance compatible with its constituents. Because TÜRK-İş is mainly organized in State Owned Enterprises and the public sector, TÜRK-İş's interest in keeping the state-centric organization of the Turkish economy and securing the subsidies and the protection of the government is at odds with the economic requirements of the EU. The EU requires that candidate countries have a liberal free-market style economy. It is not surprising that TÜRK-İş toughened its anti-EU position beginning the year 2000, in response to the Turkish 
government's privatization efforts. In 2000, the Turkish government privatized State Owned Enterprises worth $\$ 2,716,500,000.00$, while SOEs worth almost half this amount were privatized in $1998(\$ 1,019,700,000.00)$ and a similar amount in 2004 $(\$ 1,265,700,000.00)$.

The second reason for TÜRK-İş's anti-EU stance is related to the EU's structure of 'social partnership.' TÜRK-İş sees the ETUC not as a trade union confederation that is watchful of workers' interests but rather as a neo-corporatist institution designed to help the EU execute its policies. Yıldırım Koç (2003a: 52), who represented TÜRK-İş in ETUC Congresses, argues that European labor's interests are in line with the interests of European employers and governments and that European workers are a part of the imperialist system that the EU represents. Koç (2003a: 52) posits that the Commission's financing of some of the ETUC's projects is a clear example of the corporatist relationship between the EU and the Confederation. Yıldırım Koç actually calls the EU 'the United States of Europe' and 'the European Union State,' which helps him to frame his argument in the context of corporatism as well as implying the 'imperialist' policies of the EU by the wording 'the United States of Europe.' The imperialism rhetoric is still prevalent in Turkish workers' discourse. Both TÜRK-İs and DISK representatives voice their concerns over the 'imperial capitalist' nature of the EU and how it is an elitedriven institution serving the interests of the employers (Koç 2003b; Yıldız 2004).

51 The third reason for TÜRK-İş's anti-EU stance is due to its nationalist attitude that became especially prevalent after the 1992 change in its management cadres. In every forum, TÜRK-Iș officials criticize the EU's stance on the Kurdish, Armenian and Cyprus issues. TÜRK-İş argues that these issues are matters of national sovereignty and that the EU has ulterior motives in demanding a transformation of Turkish policies. According to Yıldırım Koç (2003b),

'The European Union's demands for Turkey [to change its above mentioned policies] are in opposition to the Turkish Republic's unitary state system and its independence. Abiding by these demands would tear our country apart and divide it, creating a new Yugoslavia. Turkey is not going to solve its problems through the EU. Turkey is not going to be stronger because of the EU. Turkey is going to solve its problems despite the EU, and it will be stronger. Turkey's admittance to the EU is dependent on this strength.'

TÜRK-İs's doubts about the EU's structure and how the EU membership would affect Turkish national interests created friction between the trade union confederations. In 2003, TÜRK-İş criticized the other trade union federations (DİSK, HAK-İş and KESK) because of the project-based financial aid they had taken from the ETUC. Given that TÜRK-Iş has kept a very close relationship with Turkish governments, especially up until the 1990s, their criticism on the total independence of trade unions is not very convincing. TÜRK-İs has been the target of vehement criticisms from the trade union community. One representative from DISK, for example, argues that TÜRK-İş criticized the project-based funding from the EU for other trade union confederations because there was competition between the trade union confederations to receive the funding and TÜRK-İs could not compete with the other confederations, and thus TÜRK-İş subsequently acquired a hostile attitude towards the EU and whoever works with the EU (Interview with the DISK representative, İstanbul, 2004). The HAK-İş representative, on the other hand, charges that TÜRK-İş does not know the institutional characteristics of the EU or what it means to be a member of the EU, and that is the reason for its opposition. As explained above, TÜRK-İş's international relations are interlocked with 
the developments that affect it in the Turkish domestic scene. Its opposition to the privatization policies are reflected in its position towards the EU. The changes in its ideological stance against the EU, in parallel to the political developments in Turkey, reinforce the hypothesis that the appeal to the international ally depends on the degree of salience.

\section{TÜRK-İş's Appeals to the EU}

53 After the 1999 Helsinki Summit, TÜRK-Işs started making appeals to the EU in its activities such as agenda-setting, lobbying to push for domestic policy change and changing institutional procedures in Turkey. Until that time, TÜRK-İş concentrated its activities on the national level, only occasionally alluding to the international labor standards of the ILO or the ICTFU. Between the 1960s and 1980s, the confederation's relations with international organizations were limited to 'moral support, sharing technical information and consultation' (Tokol 1994: 73). Between 1980 and 1994, Tokol (1994: 129) suggests that despite some disruptions, TÜRK-İş continued its relationships with the ICTFU and the ETUC. In the 1990s, when all trade union confederations were redefining themselves and their policy positions, TÜRK-İş chose to oppose EU membership, although its stance changed after 2004. Asked about why they would/not interact with the EU, TÜRK-İş representative argue that the domestic and international prestige, information that they get from their European counterparts are important. What the respondents name as domestic and international prestige is actually representative of their concerns about their own organizations' legitimacy and is illustrative of how they use the EU in their discourse. Below, the paper presents how the organization establishes its stance against the EU.

\section{Setting the Agenda}

TÜRK-İş organized major strikes and boycotts between 1989 and 1995, demonstrating strong opposition to the employer groups and the government (şenalp, Reyhan \& Köse 2003: 16). These strikes and boycotts mainly protested the privatization practices. Between 1995 and 2000, the strikes continued, reaching a peak in 1997 and 1998. All these strikes attracted public attention and kept the workers' problems on the agenda. Only in its 1995 General Assembly report did TÜRK-Iş allude to the EU. The report announced that 'the undemocratic 1982 Constitution and its legal framework shall be transformed in a way that it is aligned with the universal democratic principles of the international accords to which Turkey is a signatory. It should also be brought to the standards that the EU sets since we applied for membership' (TÜRK-İş history).

Yet in December 2001, TÜRK-İş declared its opposition to the EU by presenting an antiEU report to the President. The report was titled, 'What does the EU want from Turkey?' and it focused on the political criteria that EU membership necessitates. The report criticized the EU policy positions on Cyprus, Armenian issues, and minority rights, arguing that the EU is trying to carve up the Turkish republic. The report was thus a declaration of TÜRK-İş leadership's political views rather than a statement of social rights pertinent to Turkish workers' needs.

56 In June 2002, TÜRK-İş placed a full-page anti-EU advertisement in a Turkish daily. Çelik (2004: 79) quotes the advertisement, 
'They [those who support the EU membership and the changes of the harmonization process] are being disrespectful to the Turkish nation's history, abilities and goals by arguing that Turkey would turn into a Middle Eastern authoritarian state if Turkey does not do everything the EU requires. This is a submissive act.' media attention was 'TÜRK-İş's View of the EU during the Acccession Process.' TÜRK-İş asked three thousand employees about their views on the EU before the EU decision to start the accession negotiations in October 2005. This survey revealed that 65 percent of the workers surveyed believed that joining the EU would be beneficial for them in their work-life, while the remaining 35 percent disagreed. Then 85 percent of the workers answered 'no' to the question, 'Should Turkey become a member of the EU no matter what?' Even the wording of this question implies TÜRK-İş's disinclination towards the EU membership. More questions implying the EU's negativity are included in the survey, such as 'Do you think the EU is putting Turkey off?' or 'Do you believe that the EU is going to give a date for the start of negotiations in December 2004?' All these questions are worded in a way to raise the suspicion of the interviewee about the EU.

After the EU's 17 December 2004 decision to start the membership negotiations in October 2005, some of this reticence seems to have softened. On December $19^{\text {th }}$, TÜRKIss reported that it would launch a program to improve the workers' rights to surpass the EU standards. The education secretary of the Confederation, Mustafa Türker, argued that the president of the EU Parliament, Josep Borell Fontelles, urges the trade union confederations to have more say during the European Summits and supports TÜRK-İş's attempts to improve workers rights in Turkey (Birgün, 12/19/2004). This is an important example of the rapid change of attitude in TÜRK-Iş, as Türker's mention of Borell can be interpreted as a way of legitimizing TÜRK-İş's attempt to change Turkish practices. Since 2004, TÜRK-İş has not been engaged in an agenda-setting activity similar to the organizations' vehement reactions to the EU during the late 1990s. Today, TÜRK-İş publishes reports on the Turkey's adoption of the EU acquis on its website, criticizes the Turkish national program's insufficient measures on social policy and follows the Turkish- EU negotiation process closely (TÜRK-İş 2009 a)

\section{Lobbying for Policy Change}

TÜRK-İş's use of the EU in policy-related arguments is relatively new. As explained above, TÜRK-İş is primarily interested in two issues: labor laws that limit the workers' rights and the privatization policies of the state. The European Community Charter on Fundamental Social Rights for Workers (1989) and the revised European Social Pact (1989) include far greater freedoms for workers than the Turkish laws. According to one trade-unionist, TÜRK-İş activities may have been counter-productive, actually hurting the process of improving social policies. 'With its reluctant attitude towards the EU, one can argue that TÜRK-İs contributed to the insufficiency of the reforms on social policy. TÜRK-İş made the reform process harder' (Çelik 2004: 79). TÜRK-İş's antiEuropean stance undermined the negotiations within the Economic and Social Council and its criticisms of the other trade union confederations that were cooperating with the EU created uneasiness in the Turkish-EU trade union relations. 
K-Iş's criticisms went as far as hurting the European Trade Union Confederations credibility in regional discussions. In 2000, Yıldırım Koç, the TÜRK-İş representative to the ETUC, noted in an ETUC meeting about the Balkan Stability Pact that the ETUC's efforts at creating such a pact would not be beneficial to the European workers and would jeopardize the sovereignty of these countries (Koç 2003a). Having discredited the institution's policies, Koç was suspended from the working group of the Balkan Stability Pact.

61 TÜRK-İş's extreme opposition has softened, especially with the rising voices of strong trade unions within the Confederation defending EU membership. Kristal- İş and Petrol- İs, for example, point out the benefits of EU membership to the Turkish workers' movement. Aziz Çelik from Kristal- İş suggests that adoption of European social norms and practices represent a positive step for Turkish workers and trade union confederations, and that TÜRK-İş needs to actively support Turkey's membership and work with its European counterpart (the ETUC) (Radikal, 6/18/2002). Petrol- İs, on the other hand, has decided to 'turn the EU harmonization process into an advantage for the trade union,' and 'it is looking forward to the changes in the trade union laws' (Petrol- İş 2004).

accord with these ideas, during the opening of the Turkish Economy Congress, TÜRK-İş President Salih K1liç (2004a) concluded his speech by saying, 'We should take our place in the modern world by targeting the European Union's social model, and integrating into the Union.' TÜRK-İs seems to have transformed its discourse back into that of its old days, suggesting that 'modernization' is a primary goal of the Turkish Republic and that the path to modernization proceeds through Westernization, which is represented by the EU. In fact, during the Board of Presidents meeting in 2004, Salih K1lıç (2004b) argued that, "Membership in the EU is a primary national goal for Turkey. It is the biggest step in the modernization project that the great leader Atatürk designed.'

63 The end of the extreme opposition to EU membership within TÜRK-İş is also due to the change of the management cadres. President Bayram Meral resigned from his post when he was elected as a parliamentarian for the Republican People's Party (CHP) during the 2002 elections. Today, TÜRK-İş president appeals to the European standards of syndical rights as well as collective bargaining, strike and lockout agreements while preparing the draft laws (TÜRK-İş 2009 b).

\section{Changing the Institutional Procedures within Turkey}

The incorporation of workers' organizations in the decision-making procedures of the Turkish government after 1980 occurred gradually. Under the Turkish Ministry of Labor, a Labor Assembly was created in 1946 in order to bring together the interested parties to discuss issues related to all areas of working life and labor. Although the Assembly has only a consultative role, it constitutes an area of discussion between the employer associations, trade confederations, the Scientific Board (which consists of academics appointed by the national education board), and related government agencies. The Labor Assembly convened five times between 1946 and 1971 and three times between 1971 and 1992. The next meeting of the Labor Assembly did not take place until 2004, when the Minister of Labor and Social Security stated that the Ministry sees the Labor Assembly as an important platform to improve the social

European Journal of Turkish Studies, 9 | 2009 
dialogue (MLSSb: 4). During the 2004 meeting, TÜRK-İş President Salih Kılıç alluded to the social dialogue practices in European countries, arguing that Turkey should follow that example (MLSSb: 62).

TÜRK-İs participates actively in the decision-making processes in which it is included by law, or by the discretion of the government. The confederation is represented in the Economic and Social Council and in the EU-Turkey Joint Consultative Committee. TÜRK-İs also organizes working groups on legal issues that are of interest to employees and presents its resolutions to lawmakers through these two institutions. In April 2004, for example, a working group composed of TÜRK-İş representatives, lawyers and professors came together to discuss the draft legislation on trade union law (TÜRK-İş 2004: 25), indicative of its move to strengthen its research branch.

In short, TÜRK-İş appeals to the EU, especially in its agenda-setting activities. Because the confederation's constituency is directly affected by the privatization policies that are required by the global economy and the EU, however, this appeal is in the form of criticism. TÜRK-İss's views on EU membership have changed significantly in the 2000s, from the negative implications of EU membership to the positive social policy outcomes. The confederation used to portray the EU as an outside power pressuring Turkey to give up its sovereignty (on Cyprus, Armenian and Kurdish issues) and to carry out privatization projects. Especially under the leadership of Bayram Meral, TÜRK-Iş used the EU in its discourse to criticize the government and its policies. Even on issues that are of immediate interest to workers, such as the right to collective bargaining and strikes, TÜRK-İş did not pursue a strategy of lobbying the Turkish government by using the European Union as a tool. Yet, after the EU declared that the negotiations for full membership would start in October 2005, TÜRK-İş started to soften its position towards the $\mathrm{EU}$ and has increasingly delineated the benefits of $\mathrm{EU}$ membership for the Turkish trade unions movement.

\section{Confederation of Revolutionary Trade Unions (DISK) and Its Relations with the State}

The Confederation of Revolutionary Trade Unions (DISK) is the only confederation in this research that has a leftist ideology. DISK has been subjected to severe repression in the 1980s, dismantled and its leaders put in jail. In 1991, when the confederation regained its legal status, and re-opened, its reappearance has been important in the Turkish labor movement, giving it a new dimension in parallel to the EU social agenda. With the changing environment of the 1990s, DİSK reformulated itself as a confederation in line with the European trade unions. ${ }^{3}$ DISK, with the liberalization of the domestic environment started to appeal more to the EU, especially in its lobbying activities, and the organization's reformulation of itself changed its perceptions of the EU.

DiSK brings together 22 trade unions and has 312,990 members. DISK spun off from TÜRK-İş in 1967. Earlier, in 1961, a group of 12 trade unionists from TÜRK-İş founded the Turkish Worker's Party (TIP) which was the first Marxist party to win seats in the parliament (Sayar1 2002: 187). Trade unionists who sympathized with this party founded their own confederation in 1967. DISK declares on its website that its understanding of trade-unionism is based on class relations: '(T)rade Unions are the part of the contradiction and struggle between labor and capital. Workers exploited 
and crushed by capital come together within trade unions to defend their interests' (DISK 2004a). Until the 1980 military coup, DiSK's class-based ideology placed the confederation in opposition to TÜRK-İş. DİSK quickly became the rival to TÜRK-İs, and pursued an agenda against the state's policies. The 1980 military coup, however, hurt DíSK the most since the confederation was banned for over a decade. DísK also suffers from a lack of financial resources. Gaye Y1lmaz (2004), a DíSK official, argues that only four of the twenty two members of the confederation pay their dues to the confederation regularly since the member trade unions are also experiencing financial difficulties.

One of DİSK's founding principles was to fight for worker's rights using any means possible. In contrast to TÜRK-İş's attempts at staying 'beyond party politics,' DİSK declared that '(P)rofessional struggle is not sufficient for attaining the full rights of workers. It must be complemented by political struggle, utilizing all of the democratic rights enumerated in the Constitution' (Frederick Ebert Stiftung 2004). The political aspect of DisK's activities put the state and the confederation on opposite sides. DISK cooperated with student unions, and argued for an 'independent' and 'anti-capitalist' system in Turkey. The 1970s were the most problematic years in Turkish economic and political history. A series of coalition governments that were composed of political parties fundamentally opposed to one another were ruling the country and there was no consistent economic policy. With the oil crisis of 1973 and the American embargo following the Cyprus intervention, the economy deteriorated further (Müftüler- Baç 1997: 78), resulting in low wages and high inflation.

By 1975, when the center-right Justice Party (JP) became the leader of the so-called National Front coalition, the gap between the right and left grew (Sayar1 2002: 14). With the JP-led government moving further to the right, both the political left and right radicalized and political violence escalated, coming to an end with the 1980 coup. The military regime closed down and confiscated the assets of DISK and its affiliated unions. The military regime put DISK officials on trial, demanding the death penalty for their 'attempts to demolish the constitutional regime' (Frederick-Ebert-Stiftung 2004). After years of trials, the Military Court of Appeals acquitted the union leaders in 1991 and DíSK was able to resume its activities.

71 In June 1992, the leaders of all DISK affiliates assembled to discuss the future of the Confederation. They concluded that "unionization in general had severely declined, the former union cadres had almost disappeared, and most of their former members were retired or otherwise withdrawn from the labor market. This situation, coupled with the aggression of the employers and the changes in production and technology required the formulation of new trade union policies." Confronting this charged environment, DíSK started to form affiliations with other trade unions, and spearheaded the creation of the Democracy Platform. In addition, DISK advanced its relations with international organizations such as the ICFTU and the ETUC.

\section{International Linkages, Relations with the EU}

72 In its early years, in line with its Marxist disposition, DISK established relationships with Soviet-satellite third world countries. It had also applied for membership in the ETUC in 1973, but had been rejected (Frederick-Ebert-Stiftung 2004). During the 1970s, some of DiSK's affiliate trade unions made connections with international trade secretariats (Tokol 1994: 73). These international trade secretariats were affiliated with 
the ICFTU and other international confederations. Some Turkish trade unions were thus indirectly linked to the international trade union movement.

The Turkish government's ban on DISK following the 1980 coup raised international awareness for the Turkish union movement, and the ICFTU, the ETUC, the ILO and the EU kept DISK on their agendas (Tokol 1994: 103, 110). In 1982, the European Parliament criticized the military courts that put the trade union members on trial and requested that the Council and the Commission freeze EU-Turkish relations. In 1985, the ETUC granted membership to DİSK. As a result of international pressure combined with progressive internal developments, DíSK was reinstated in 1991. After 1992, DíSK joined the ICFTU as well.

Since its inclusion in the ETUC, DISK prioritized its relations with its European counterpart, being the only Turkish trade union confederation that has a permanent representative in Brussels. ${ }^{4}$ DISK views the Turkish trade union movements' interests lying with the EU and establishes relationships with the ETUC in order to pursue Turkey's membership in the union. DISK representatives underline the importance of Turkish membership in the EU and the benefits it will bring to the Turkish working class.

Süleyman Çelebi, president of the confederation declared in 2001,

'The European Union does not consist solely of an economic partnership, it has a social aspect. This social aspect has been developed over the years by trade unions of member countries. Trade unions have gained social rights in their own countries after years of struggle and the EU today presents a combination of all these social rights. In addition, European trade union movement constantly pressures the EU and the member countries to improve these rights. Turkey is required to make changes to its social policies and improve the Turkish workers' social rights as well. The Partnership for Association document, for example, requires the Turkish government to review the provisions of the Constitution on the rights of trade unions and employer associations in near future' (Doğan 2003: 33-34).

Çelebi's comments clarify that DISK is aware of the changes that EU membership will bring and that it supports the EU consciously. DISK states this about its international relations: 'DISK has given prime importance to the international struggle of working class since its establishment. It has become a member of the International Confederation of Free Trade Unions (ICFTU) and the European Trade Unions' Confederation (ETUC) in order to attain class solidarity and to carry the struggle for the rights and freedoms of workers to the international level' (DISSK 2004a).

Asked about the reasons of its support of relations with the EU, respondents argue that first, the EU's provisions are better for workers, second, the EU supports workers' training and increases DísK's informational capacity. International prestige is the last reason that respondents provided for DISK's interaction with the EU. Having stated the reasons, what are the ways that DISK appeals to the EU?

\section{DiSK's Appeals to the EU}

DiSK, cognizant of the improvements that EU membership could bring to Turkish social policies, appeals to the EU by both agenda setting activities and lobbying. It lobbies the Turkish government to change its policies according to EU standards, and to gain support for Turkish membership. DiSK's Brussels representation takes an active role in ETUC activities related to Turkey. 


\section{Agenda-setting}

79 After its reinstatement in 1991, DİSK skillfully transformed its organization. Under economic globalization DİSK maintained that a successful trade union movement is only possible through international collaboration. Süleyman Çelebi asserts,

'In face of the problems that arise with globalization, international collaboration becomes more important. Laborers of our country should be members of this process, instead of being subjected to the effects of globalization passively. Crises in one country or region spread rapidly to others. Therefore, we should be active participants in international struggles and cooperation.

Within the EU, there is a strong effort to improve the existing rights of workers. Our country's laborers should understand that these efforts, to which they have not paid attention so far, are going to influence their lives. We cannot pursue our struggles solely on the national front any more. We have to support the laborers of the EU countries in their struggles' (Doğan 2003: 33).

DISK argues that reaching European standards of social policy is more important than being a member of the EU.

Alluding often to the necessity of Turkish membership to the EU, DISK designed and participated in specific European Commission projects such as the MEDA-TURKEY Project for Civil Society: Trade Unions and Democracy and the Europe Initiative for Democracy and Human Rights. These projects call for the training of Turkish workers and trade unionists in EU-related issues. For instance, under the Europe Initiative for Democracy and Human Rights project, named 'Human Rights for All.' Three hundred DISK members from six regions of Turkey are trained to give human rights lessons to ten workers within their region. Via this project, DISK raises awareness for human rights. DISK's effort at training workers and involving labor in human rights debates is an attempt to improve Turkey's human rights record, the target of continued EU criticism.

\section{Lobbying for Policy Change}

DISK appeals to European social policies when it is lobbying the Turkish government to change its policies. For instance, the Democracy Platform (then Labor Platform) of which DisK is a founding member declared in its program that the government should ratify the articles of the European Social Charter, including workers' right to organize (Article 5), bargain collectively (Article 6), children's rights (Article 7), and women and children's right to economic and social protection (Article 17).

3 The 2003 labor law has stirred up vehement debates between employers, employees, and the government as well. Briefly, Turkish job security laws and the legal rights workers have vis-à-vis the employers during expulsion from work are not well developed and even the latest changes introduced during the harmonization process cannot meet the European standards. Employers' unions, exercising their leverage against the government, shaped the work law in their own interests to the detriment of workers. DISK points out the insufficiency of the current law and argues for bettering it by raising it to European standards. The general secretary of DİSK Musa Çam (2004) argues,

'The work law that entered into force in June 2003 does not meet the EU harmonization criteria. The 2004 National Program [the changes that the Turkish government declares it is going to carry out to comply with the EU criteria] 
promised a solution to this problem and the Minister of Labor and Social Security has admitted that the changes introduced fall short of meeting even the lowest European standards...The National Program's section on Social Policies and Labor, however, do not reflect the EU acquis. Especially the topics of collective expulsion, transfer of work place, responsibility of the employer to inform the employees of conditions related to contracts... are not included in the National Program.'

By comparing the Turkish laws and EU directives on social policies, Çam (2004) promotes the improvement of Turkish workers' rights. DISK also publishes research on different European countries' social policy practices to support its arguments (DisK 2004b). During the discussions of the draft law on trade unions that is high on the agenda in Turkey in 2009. DisK follows a similar strategy. By showing the discrepancies between the Turkish and European practices, DisK tries to push the Turkish government to change its policies.

\section{Changing Institutional Procedures}

DISK has been a strong force in changing Turkish institutional practices and taking part in the decision-making procedures of the state via its linkages with the EU. DiSK participated in the foundation of the Economic and Social Council as well as the EUTurkey Joint Consultative Committee; and its Brussels representation has established relationships with the ETUC (Doğan 2003: 32).

DISK, as the only Turkish trade union confederation with permanent representation in Brussels, participates in the EU-Turkey Joint Consultative Committee, by giving expert advice to the European side about Turkish civil society (Doğan 2003: 32). DíSK's Brussels representative Yücel Top also acted as the coordinator to launch a Turkish Trade Union Coordination Commission. Within the MEDA-TURKEY Project for Civil Society: Trade Unions and Democracy, Yücel Top coordinated a Commission composed of three Turkish trade union confederations (DISK, KESK and HAK-İş). This Commission provided a resource center to Turkish trade unions in all areas touching on relations between Turkey and the European Union by accumulating reference material as well as carrying out studies and groundwork for joint activities. The Commission started its operations in late 2001 and completed its projects in 2004.

DISK enjoys exceptionally good relations with the European trade unions confederation, the ETUC. In 1985, when the European confederation granted DISK membership, it also appointed Kemal Baştürk, then the president of DísK, to its executive board. While this was more of a symbolic gesture (targeted towards the Turkish government, signaling that the EU does not approve of the military coup and its rule), it opened the way for DISK executives to deepen the relations later on. Indeed, after its reinstatement DISK was actively involved in the ETUC. In 1992, DíSK coorganized and hosted the ETUC's Balkan Trade Unions Confederation meeting in Ankara. DISK participates in the ETUC's executive committee meetings as well. In sum, DISK is an important actor in Turkey's relations with the EU and actively participates in the decision and policy-making procedures of the government.

Started in the late 1960s with a revolutionary ideology, by the 1990s DisK transformed itself into a progressive trade union confederation which is supportive of Turkish membership to the EU. DİSK has established strong relations with the ETUC and participates in various institutions founded during Turkey's harmonization process to the EU. The confederation uses its linkages with the ETUC and its place in transnational 
institutions to pressure the state to change its policies. DİSK's case clearly demonstrates that to what extent the organization is limited is of great importance to the latter's appeal to the EU. When DISK was closed down, having no political opportunity, it could not have appealed to the EU. As mentioned above, now the Brussels representative had interactions with his European friends, but the 'appeal to the EU in order to change state policies' as this research postulates could not have happened since this research focuses on a domestic organization's appeal to the EU, not on the informal linkages founded. The case also proves that DisK's reformulation of itself in the 1990s and its alignment with European trade unions is a very important factor in this appeal to the EU. Prioritizing the same issues, EU became a critical ally for DísK.

\section{Confederation of Justice Seekers' Trade Unions (HAK-iŞ) and Its Relations with the State}

Confederation of Justice Seekers' Trade Unions (HAK-İs)'s stance towards the EU has changed through the years, and the liberalization of the domestic environment has helped the confederation to establish interactions with the EU. HAK-İs's appeal to the EU has been intricately linked with the organization's liaisons with the government. When the government was pursuing the EU, its appeal to the EU has been strong, and vice versa.

HAK-İ̧ is the third confederation of trade unions in size, bringing together nine trade unions totaling 235,676 members. HAK-İş's main source of income is membership fees as well. HAK-İş representatives did not complain of financial difficulties, contrary to DISK (Interviews, Ankara, 2004). HAK-İş, founded upon Islamist ideologies during the radical polarization of the 1970s, was not an active player in the Turkish trade union movement until the late 1980s. The confederation actually defines its history by breaking it down into three phases, 1976-1980, 1980-1984 and the period since 1984. The first two phases are referred to as 'the founding years' and 'the prohibited and lost years' respectively (HAK-İş 2004a). HAK-İş was closed down by the 1980 military coup. Although it was reinstated the following year, the confederation did not become active again until the 1990s.

91 In HAK-Işs's ideology, the employer-employee interests are not conflictual. Rather, the confederation posits that 'HAK-İs is going to weigh the rights of the employers and employees in a balance of justice and it will grant the rights to those who deserve them' (Tokol 1994: 61). HAK-İş, like TÜRK-İş, supports cooperation among the major actors.

92 HAK-Iş is known to have had close relations with the Welfare Party (WP, known in Turkish as the Refah Partisi or RP) which was closed down in 1998. Necati Çelik, an expresident and an important figure of the confederation, was elected as an MP from the Welfare Party in the 1995 elections and became the Labor Minister in the coalition government (Doğan 2003: 34). HAK-İş maintained its relations with the newcomer Islamist parties, and established especially good relations with the AKP, which skillfully transformed the Islamic discourse into a pro-European Union stance. The president of HAK-İs declared in the November 1999 general assembly that:

'...HAK-İş...wants Turkey to pursue a peaceful foreign policy based on mutual interests and abide by the rules and norms of international agreements such as the European Social Charter... HAK-İş expects and demands a state that organizes its 
Constitution according to international norms, and one which respects democratic principles, human rights, and freedom of thought' (Doğan 2003: 35). Given the organic relations between the ruling party and the confederation, HAK-Iş does not have difficulties in voicing its concerns to the government. HAK-İş's strong support for EU membership seems to have facilitated friendly relations as well. The president of the confederation joined the current Prime Minister Recep Tayyip Erdoğan, who at the time had not been able to assume the post because of legal impediments, during his visit to Copenhagen in 2002. On the other hand, during the interviews, a lower level official complained that the current government does not include the trade union in its European-level activities. The interviewee (Ankara, 2004) argues:

'Former governments (Mesut Y1lmaz, the Prime Minister between 1997- 1999, and şükrü Sina Gürel, Minister of State from 1997 to 2002), used to ask us to go and lobby the EU, whereas this government does not include us in its lobbying activities. They founded the European Union Communication Group and included the employer organizations; they did not take us in.'

HAK-İs is included in many initiatives that were started by the government, and according to many, it actually enjoys some privileges because of its closeness to the government. For example, HAK-İs is a member of the Reform Monitoring Group, a government initiative to examine the implementation of the political reforms, and of the Ministry of Industrial Relations' Board on Advertisements. HAK-İş is thus included in the government initiatives that encourage civil society participation. The interviewee from TÜRK-İş, as well as the employer groups and other CSO representatives, all agree that HAK-Işs's Islamic background and its close relations with AKP provides it with leverage with the government over other trade unions.

\section{International Linkages, Relations with EU}

HAK-Iş's stance towards the EU has changed over time. Similar to the Turkish Islamist movement, which has became a staunch supporter of "Westernization" and the European Union, HAK-İş transformed itself from being anti-European in the 1980s and early 1990s into being pro-European. In December 1989, HAK-İş declared its stance towards the EU:

'A major challenge to integration with Europe is Turkey's Muslim population. Turkey, because of its historical, moral, philosophical, religious and national characteristics, is not Western. 'Westernization' comes as a betrayal and alienation to Turkish culture... if membership in the EU is pushed; this would mean a total surrender [to Western values]. On the other hand, Turkey's application for EU membership means a heavy legal burden for the Constitution and other laws, and constitutes a threat to state's sovereignty and nation's unity...the fact that the government and the opposition parties are silent about this raises questions' (Çelik 2004: 79).

In 2003, however, HAK-İş declared that the legal changes and Constitutional reforms that have been made for accession purposes are 'a further step in the Westernization and modernization process that Atatürk launched' (Çelik 2004: 79).

HAK-İş has developed a strong technical team specializing in the EU, and partly due to its close relations with the government, it has managed to participate in the decision and policy-making processes of the state. 'HAK-İş is successful because they have done 
what the other trade-union confederations could not,' says one interviewee (2004, İstanbul). HAK-İş masters technical information about the EU processes, launches transnational relations and effectively participates in the government's activities concerning the EU harmonization process. the public's or its own members' awareness about the EU. It does, however, organize seminars and conferences and send its officials to international conferences and training sessions. HAK-Isş emphasizes creating a technical team of experts on EUrelated issues and invests in sending its members to Europe for informational purposes. Osman Yıldız, now the confederations' international affairs director, was sent to the London School of Economics for a master's degree (Ylldız 2004). Ünal Özdem, the press 
consultant for HAK-Işs, went to Copenhagen and Strasbourg to participate in a training session to 'Increase Knowledge about Human Rights and Democracy' (Özdem 2004).

HAK-İ̧ was also one of the recipients of ETUC funds for improving civil society in Turkey, the MEDA project. Using MEDA funds, HAK-iş focused on 'information and training for Confederation leadership and officials on Turkey's integration into the EU through local/regional seminars and setting up a "regional information superhighway"' (ETUC 2002). In 2003, regional officials of HAK-İş from Ankara, Bursa (western Turkey) and Elazığ (eastern Turkey) have completed their training sessions on the EU (HAK-İş 2003: 81). As a member of the Turkish Trade Union Coordination Commission, HAK-İş also participated in the commission's activities. Salim Uslu, president of the confederation, participated in the July 2003 seminar on the "Broadness and Differences of Turkish Trade Union Movement," for example (HAK-iş 2003: 79).

\section{Lobbying for Policy Change}

HAK-Iş is reported to be able to voice its concerns to the government more easily than the other confederations thanks to its political affinity. Yet, it uses the EU in its arguments to promote the European standards for social policy. For example, at the Labor Assembly convened in 2004, HAK-İş argued that '...the European Strategy of Employment ought to be followed. This strategy calls for increasing the employment rate via occupational training, encouraging entrepreneurship which means more and better jobs, and ensuring equal opportunity to workers' (HAK-İş 2004b). HAK-İş refers to European practices in most, if not all, types of discussions concerning work relations. HAK-İs strongly supports the EU sponsored 'social dialogue'. Salim Uslu (2004) calls for cooperation between the employers, employees and the government and calls the employers and employees 'social partners' in shaping the state's socio-economic policies. Given HAK-İs's corporatist style, and its emphasis on collective problemsolving, this view is consistent with the confederation's approach.

When the government announced the minimum wage for 2005, HAK-İş contended that the new minimum wage is not enough for the social development that EU membership necessitates (HAK-İş 2004e). HAK-İş's comments about the new minimum wage may be interpreted as appealing to the EU standards in order to change the policies of the government. Yet, compared to other organizations, HAK-Iş's rather muted criticism of the government on an issue of fundamental importance to labor makes this interpretation problematic.

TÜRK-İs and DISK have loyal supporters and long histories of working with the EU, while HAK-Iss is a relative newcomer to the Turkish trade union movement as well as to the international arena. Its flourishing relations with the EU come at a time when the Turkish government is also prioritizing EU membership. Therefore, HAK-İs's dedication to the EU may stem from its positive relations with the ruling party, the AKP.

In addition to its strongly European stance, HAK-İş also enjoys relations with Middle Eastern trade unions. After the death of Palestinian leader Yasser Arafat, for example, the president of the confederation sent sympathy messages to Palestinian trade unions as well as visiting the Palestinian Ambassador in Ankara (HAK-Iş 2004c). Whether HAKİs has actually internalized European norms and procedures and is trying to position itself in a interdependent world with transnational linkages both to Europe and the 
Middle East or rather has some hidden agenda as some secularists believe and is only using European discourse for other purposes is yet to be seen.

\section{Changing the Institutional Procedures}

HAK-Iş, along with other trade union confederations, takes part in state sponsored institutions such as the Economic and Social Council as well as civil society initiatives like the Labor Platform (formerly the Democracy Platform). In cooperation with other civil society organizations within the Economic and Social Council, HAK-İş prepared reports during 1997-1999 to improve the council's composition which suffers from state's dominancy (HAK-i̇ş 2003: 65).

In its deliberations with other institutions and employers, HAK-İş takes a cooperative stance. For example, HAK-isş's president declared during the Turkish Confederation of Employers' Associations' (TISK) general assembly that 'During the negotiation process with the EU, employer and employee associations cannot leave everything to the government. Civil society organizations ought to be in close cooperation with the state and the government ought to be more open to dialogue' (HAK-İs 2004d). During the same meeting, Salim Uslu also argued that since the EU directives maintain that the relations between the employers, employees, and the state ought to be in the form of a social partnership, the civil society organizations ought to come together to discuss the laws related to work life, and take it to the government afterwards. He also said that "we have to show our abilities of mediation and cooperation as well' (HAK-ìs 2004d). This discourse is different from other trade union confederations' approach to the relation between the three actors. TÜRK-İs and DISK have adversarial approaches towards the employers groups.

HAK-Iş also participates in the Ministry of Labor and Social Security's EU Social Dialogue Committee, created for a better harmonization process with the EU. This committee brings together the social partners to discuss issues related to working life. While HAK-İş claims that it has hosted some of the meetings (HAK-İş 2003: 75), an official from the Ministry of Labor and Social Security's EU Coordination Desk stated that they have not yet established direct relationships with the trade union confederations (Interview, Ankara, 2004).

110 HAK-İş was founded on Islamic principles that criticized the West and thus Turkey's Westernization efforts. After the 1997 'post-modern coup' the new Islamic party, the AKP, softened the old Islamists' extreme opposition to the West. HAK-İs followed AKP's footsteps as well as establishing strong relationships with the party and transformed itself from being anti-European in 1980s and early 1990s into being pro-European in the 2000s. HAK-İş has developed a strong technical team specializing in EU issues which granted HAK-İş access and strength in its relations with the EU. The confederation uses the EU in its discourse to push for policy changes such as promoting social dialogue between employers, employees and the state. On workers' rights issues, HAK-İş does not seem to push as hard to alter the state's policies.

\section{Synopsis of the Findings and Conclusion}

111 Comparing three different trade union organizations, the research elaborates on the reasons why and how employees' organizations articulate their demands and preferences and convey it to the state through their EU discourse. The confederations 
are examined in light of the following research questions: domestic actors appeal to the $\mathrm{EU}$, if so, why is this appeal made, and which factors influence domestic actors' appeal most? The paper hypothesizes that the more likely the trade unions to appeal to the EU when (1) when they see their issue salient to the EU (2) the domestic environment is more liberal. Thus, contrary to the duality of the open/closed environment theses of boomerang and spiral models, the research introduces the time dimension with the liberalization variable, and accounts for the changes in the trade unions' perceptions of the EU with the salience variable. Supporting both hypotheses, evidence shows that three employees' groups vary in their motives as well as in their strategies.

After a thorough examination of each organization's activities from primary sources from the organizations as well as EU documents, interviews and newspapers, this research finds that employee organizations all appeal to the EU although their ways of appeal vary. TÜRK-İs uses the EU mostly in its agenda-setting activities to shape an anti-EU public opinion up until 2004. The organization then starts to utilize the EU's labor and social policy to push the Turkish state to improve its practices in these areas. HAK-Iş, on the contrary, does not really use agenda-setting as a policy tool. The organization emphasizes the EU in its lobbying activities and it argues that the EU's rules and procedures necessitate greater inclusion of labor in the state's decisionmaking institutions. The last employee organization, DisK, uses all three strategies. It supports European social policies in its agenda-setting, lobbying and institutional activities.

The strategy difference between the three trade union confederations is a reflection of their own organizational traits. Neither TÜRK-İş nor HAK-İs seem to have internalized the European norms and rules of labor and social policy as much as DİSK. TÜRK-İş and HAK-İs appeal to the EU on issues that are of direct interest to their organizations, but on more general issues that are of interest to all laborers in Turkey, their criticisms are rather muted. DISK, on the other hand, has been a strong supporter of the EU since 1990 and it emphasizes the importance of adopting the European standards in every aspect of work life.

As these findings and the preceding discussion of each organization's evolution show, employee organizations appeal to the EU to legitimize their stance on issues and seek domestic legitimacy. Thus, the extent to which they see the international organization as salient to their cause is very important as the first hypothesis suggests. They use the $\mathrm{EU}$ in their discourse in order to motivate their constituencies and acquire their support. For example, TÜRK-İş, whose members' interests are in opposition to EU's privatization policy, appeals to the EU by criticizing its policies. This way, the organization promotes its members' interests and tries to reverse the state's EU harmonization policy. DISK and HAK-Iş are both pro-EU. DISK appeals to the EU to change Turkish social policies and uses the EU as leverage against the state, while HAKIss appeals to the EU, supporting the government's position because its interests and those of the government are mostly congruent. DISK and HAK-İş also plan for the future of their relations with the EU and make use of the financial sources that the EU programs provide. For the employee organizations, gaining domestic legitimacy is the most important motivation to appeal to the EU. For the EU supporting organizations, improving their relations with the European institutions is the second most important motivator. For the anti-EU TÜRK-İs, international prestige has recently become a priority, since the organizations started to soften its anti-European stance. 
115 These reasons are also consistent with each organizations' place in the Turkish economic and political scene. Suffered greatly from the closeness of the domestic environment and failed to become active within the confines that were enforced upon them, trade unions still struggle to be influential in the domestic arena, and emphasize their domestic prestige. Thus, the relative openness of the environment, that this work's second hypothesis focuses on, is an important factor in domestic organizations' appeal to international allies, a factor that other studies do not emphasize.

116 Tracing the transformation of the domestic environment and its effects on interactions between domestic actors, the state, and international organizations, this study aims to add some nuance the explanations providing by the boomerang and spiral models. Turkish- EU relations are complex and Turkish domestic actors' interactions with the $\mathrm{EU}$ and the state depend on many variables, such as the history of political and organizational structures. A historical analysis of these complex relations enables us to deepen our understanding of the domestic actors' motives and behaviors, and therefore this approach can tell us more about the reasons for the models' consistency or inconsistency with other cases.

117 These findings indicate that the transnationalist literature's explanation of why domestic organizations appeal to international organizations remains limited. Being weak under a repressive state cannot alone explain why domestic organizations appeal to international organizations. Turkish domestic organizations behave very instrumentally, and use the EU as a tool to legitimize their own standing or improve their own conditions.

118 Using a theoretical framework of the transnationalist literature and refining the boomerang and spiral models' hypotheses, this research attempts to do two things. First, it focuses on transnational activism. Although the theoretical frame here is not directly involved with the organizations' transnational activism understood as their activities beyond their borders, this research shows the importance of domestic conditions for transnational relations. Second, focusing on the Turkish trade union confederations' interaction with the Turkish state and their European counterparts, it shows the linkages between the organizations' internal setting and Turkey's domestic environment. It shows how perceptions of the European Union affect Turkey's domestic arena. Thus, for further research it would be interesting to see whether other types of domestic actors' behaviors vis-à-vis the EU. For example, do the human rights organizations, on which the transnationalist literature focuses a lot, appeal to the EU in Turkey? Preliminary findings suggest that Turkish human rights organizations tend to behave very much like the employees groups. ${ }^{5}$

\section{BIBLIOGRAPHY}

Another question that needs further elaboration is the perception of other international organizations by the trade unions, a further step would thus be to examine the organizations' appeal to different international organizations, such as the International Labor Organization. 
Aker, Önder (2004) Trade Unionist, Ex-official at TÜRK-İş. Interview by author, June, Ankara.

Arat, Zehra Kabasakal (2009) 'Political Parties' Gender Discourse and Women's Rights: The Case of Turkey' paper presented at the $49^{\text {th }}$ Annual Convention of the International Studies Association, San Francisco, 26-29 March, Isanet, online.

Armbruster-Sandoval, Ralph (2003) 'Globalization and Transnational Labor Organizing: The Honduran Maquiladora Industry and the Kimi Campaign', Social Science History, 27 (4), pp. 551-576.

Ayata, Sencer (2004) 'Changes in Domestic Politics and the Foreign Policy Orientation of the AK Party,' in Martin , Lenore G. and Dimitris Keridis (eds.) The Future of Turkish Foreign Policy, Cambridge, MA, MIT Press, pp. 243- 277.

Aydın, Fatih (2004) 'Sendika Genel Kurullarının Gösterdiği Yeni Umutlar [New Hopes that the Trade Unions' General Assemblies Raise]', Ürün, Sosyalist Dergi [The Produce, Socialist Magazine], 16, (May- June), pp. 14-30.

Barkey, Henry J. (1990) State and Industrialization Crisis in Turkey, Boulder, Westview Press.

Çam, Musa (2004) ‘Çağdaşlık mı, Rekabet mi? [Modernization or Competition?]' http:// www.disk.org.tr/basin.asp?id=335.

Çelebi, Süleyman (2004) ‘AB Tartışmaları [EU Discussions]' http://www.kesk.org.tr/kesk.asp? sayfa=kesksesyazi\&id=60.

Çelik, Aziz (2003) 'Yeni İş Yasasının Anlamı [Meaning of the New Law on Labor]', Türkiye Barolar Birliği Dergisi [Turkish Union of Bar Associations Journal], 48, September-October.

Çelik, Aziz (2004) ‘AB Sürecinin En Uyumsuz Alanı: Sosyal Haklar [The Most Uneven Arena of EU Process: Social Rights] ', Birikim, Aylık Sosyalist Kültür Dergisi [Socialist Cultural Monthly], 184-185, (August-September), pp. 72-87.

Della Porta, Donatella and Mario Diani (2006) Social Movements: An Introduction, MA, Blackwell Publishers.

Diken, şeyhmus. (2006) Türkiye'de Sivil Hayat ve Demokrasi: Sivil Toplum Sorunlarını Tartışıyor [Civic Life and Democracy in Turkey: Civil Society Discussing its Problems], Istanbul, Dipnot Yayınları.

DISK (2001a). 'Emek Platformu [Labor Platform]', http://www.disk.org.tr/platformlar.asp? action=karar\&action2=view\&id=5

DISK (2004a) www.disk.org.tr (English content).

DISK (2004b) http://www.disk.org.tr/diskar.asp?id=10.

Doğan, Erhan (2003) ‘Sendikalar ve Türkiye'nin Avrupa Birliği Siyaseti [Trade Unions and Turkey's EU Policies]', Akdeniz İ̈BF Dergisi [Akdeniz University Economic and Social Sciences Journal], 6, November, pp. 19-43.

Frederick Ebert Stiftung (2004) Digital Bibliothek, Frederick Ebert Stiftung Foundation. http:// www.fes.de/fulltext/bueros/istanbul/00253009.htm\#LOCE9E9.

Fleay, Caroline (2006) 'Australian Foreign Policy, Human Rights in China and the Spiral Model', Australian Journal of Political Science, 41 (1), pp. 71-89.

George, Alexander L (1979) 'Case Studies and Theory Development: The Method of Structured, Focused Comparison' in Paul Gordon Lauren (ed.), Diplomacy: New Approaches in History, Theory and Policy, New York, The Free Press, pp. 43-68. 
HAK-İş (2004a) http://www.hakis.org.tr/tanitim/hakis_eng.htm.

HAK-İş (2004b) http://www.hakis.org.tr/arsiv/Hakis_cal_mec_rap.htm.

HAK-İş (2004c) http://www.hakis.org.tr.

HAK-İş (2004d) http://www.hakis.org.tr/arsiv/tisk_genel_Kurulu.html.

HAK-İș (2004e) http://www.hakis.org.tr/arsiv/2004_asgari_ucret.html

Hasenclever, Andreas (2005) 'Human Rights by Moral Intervention', International Studies Review (7), pp. 63-66.

Heclo, Hugh (1972) 'Issue Networks and the Executive Establishment', in Nivola, Pietro D.; Rosenbloom, David H. (eds.) Classic Readings in American Politics, New York, Worth Publishers, pp. 232-260.

Keck, Margaret E.; Sikkink, Kathryn (1998) Activists Beyond Borders: Advocacy Networks in International Politics New York, Cornell University Press.

Kerbo, Herold R. (1982) 'Movements of "Crisis" and Movements of "Affluence”: A Critique of Deprivation and Resource Mobilization Theories', The Journal of Conflict Resolution, 26 (4), pp. 645-663.

K1lıç, Salih (2004a) Speech at the İzmir Economic Congress, May $5^{\text {th }}$, http://www.turkis.org.tr/ icerik/izmiriktisat.htm.

Kılıç, Salih (2004b) Opening Speech of the Board of Governers, May $13^{\text {th }}$, http:// www.turkis.org.tr/icerik/baskurul.htm.

Koç, Yıldırım (2003a) ‘Avrupa Birliği’nin Sendika Emperyalizmi ve Türkiye'deki Faaliyetleri [The Trade Union Imperialism of the EU and Its Activities in Turkey]', Jeopolitik [Geopolitics], 8, Fall, pp. 47-58.

Koç, Yıldırım (2003b) Türkiye Avrupa Birliği İlişkileri, TÜRK-İş Eğitim Yayınları, 66, cited in Doğan, Erhan (2003) ‘Sendikalar ve Türkiye'nin Avrupa Birliği Siyaseti [Trade Unions and Turkey’s EU Policies]', ‘Sendikalar ve Türkiye'nin Avrupa Birliği Siyaseti [Trade Unions and Turkey's EU Policies]', Akdeniz İ̈BF Dergisi [Akdeniz University Economic and Social Sciences Journal], 6, November, pp. 19-43.

Lutz, Ellen L.; Sikkink, Kathryn (2000) 'International Human Rights Law and Practice in Latin America', International Organization, 54 (3), pp. 633-659.

MLSSb. Ministry of Labor and Social Security Transcripts of the Ninth Work Council, available on www.calisma.gov.tr.

Müftüler- Baç, Meltem (1997) Turkey's Relations with a Changing Europe, Manchester, Manchester University Press.

Öngün, Emre (2008) 'Action collective transnationale et contraintes de l'espace national: Enquête sur les formes de l'engagement en Turquie dans le contexte de "l'europeanisation"', Ph.D., Université Aix-Marseille III- Paul Cézanne, Ecole doctoral de Sciences juridiques et publiques.

Özbudun, Ergun (1991) ‘The Post-1980 Legal Framework for Interest Group Associations' in Heper, Metin (ed.) Strong State and Economic Interest Groups: The Post-1980 Turkish Experience, New York, Walter de Gruyter, pp. 41-53.

Özdem, Ünal (2004) Informational Report to HAK-İş Executive Board, http://www.hakis.org.tr/ arsiv/gezi_raporu.htm. 
Risse, Thomas; Green- Cowles, Maria; Caporaso, James (2001) 'Europeanization and Domestic Change: Introduction' in Green- Cowles, Maria; Risse, Thomas; Caporaso, James (eds.) Transforming Europe: Europeanization and Domestic Change, Ithaca, Cornell University Press, pp. 1-21.

Risse, Thomas (1999) 'International Norms and Domestic Change: Arguing and Communicative Behavior in the Human Rights Area', Politics and Society, 27 (4), pp. 529-559.

Risse, Thomas; C. Ropp, Stephen; Sikkink, Kathryn (eds.) (1999) The Power of Human Rights: International Norms and Domestic Change, Cambridge, Cambridge University Press.

Risse- Kappen, Thomas (2002) 'Transnational Actors and World Politics' in Carlsnaes, Walter et al. (eds.) Handbook of International Relations, London, Sage, pp. 255-274.

Sakallığlu, Ümit Cizre (1991) 'Labour: The Battered Community' in Heper, Metin (ed.) Strong State and Economic Interest Groups: The Post 1980 Turkish Experience, New York, Walter de Gruyter. Sayarı, Sabri (2002) ‘The Changing Party System’ in Sayarı, Sabri; Yılmaz, Esmer (eds.) Politics, Parties and Elections in Turkey, Boulder, Lynne Rienner Publihers, pp. 9-32.

Sissenich, Beate (2005) 'The Transfer of EU Social Policy to Poland and Hungary' in Schimmelfennig, Frank; Sedelmeiere, Ulrich, The Europeanization of Central and Eastern Europe, Ithaca, Cornell University Press.

Tıraş, Mehmet (2004) ‘Sendikalarda Trilyonlar Dönüyor [Unionists Play with Trillions]', interview by Neşe Düzel, Radikal, 12/06/2004.

Tsarouhas, Dimitris (2006) 'European Integration and Path Dependence: Explaining the Evolution of EU Social Policy', in European Political Economy Review, 3 (2), pp. 87-111.

Tokol, Aysel (1994) Türkiye'de Sendikal Hareket [Syndicalism in Turkey], Bursa, Ezgi Kitabevi.

Toprak, Binnaz (1996) 'Civil Society in Turkey' in Norton, Augustus Richard (ed.) Civil Society in the Middle East, New York, Brill.

TÜRK-İş (2009 a) http://www.turkis.org.tr/source.cms.docs/turkis.org.tr.ce/docs/file/ sendikal_hareket.doc, and http://www.turkis.org.tr/?wapp=abcalisma.

TÜRK-İș (2009 b) http://www.turkis.org.tr/?wapp=haberdetay0\&did=3941A779-FFE7-441C-9BB4D24AD39CCBB8.

TÜRK-İş (2009) http://www.turkis.org.

Uslu, Salim (2009), interview with Jale Özgentürk, 4 May 2009, Referans, http://www.hakis.org.tr.

Van Evera, Stephen (1997) Guide to Methods for Students of Political Science, New York, Cornell University Press.

\section{NOTES}

1. Keck and Sikkink (1998) look at Argentinean human rights groups in 1970s, Lutz and Sikkink (2000) apply the boomerang model to Latin American countries, so does Armbruster- Sandoval (2003) to Honduras' labor organization. Fleay (2006) explains the Sino-Australian relations on human rights issue with the help of the spiral model.

2. For a comprehensive discussion of how KESK was founded, and how its relations with its European counterparts developed, see Emre Öngün, Action collective transnationale et contraints de l'espace national: Enquête sur les formes de l'engagement en Turquie dans le contexte de l'europeanisation, 
(unpublished Ph.D. diss., Université Aix-Marseille III- Paul Cézanne Ecole doctoral de Sciences juridiques et publiques, 2008).

3. Surely, European trade unions cannot be taken as a static homogenous entity, yet DíSK, contrary to the other Turkish unions studied here is much more in line with its European counterparts and ETUC.

4. DISS's Brussels representation is headed by Yücel Top, who has been very influential in the Turkish trade union movements' international linkages. This one man representation is actually an ironic story in Turkey's democratization history. As Öngün (2008) points out, Top had to flee from the 1980 coup and lived in Europe since then, establishing contacts with his European colleagues there.

5. Two human rights organizations that have been under strong pressure from the state as well as from some parts of the society were added to the sample. Organization for Human Rights and Solidarity for Oppressed People (MAZLUM-DER) and Human Rights Association (IHD) are both advocates of civil and political liberties. MAZLUMDER strongly opposes to the ban on the head-scarf, which is a sensitive issue for the staunch Kemalist secularists in Turkey, and IHD is mainly organized in Southeastern Turkey and a supporter of better human rights for Kurds. Being under stronger pressure, these two organizations would be expected to appeal most to the EU. This did not hold true. MAZLUM-DER sees the EU as a potential force on the state, but the organization is keen on stressing the importance of internal dynamics, Turkish civil society's liveliness. MAZLUM-DER uses the EU in its appeal very instrumentally as well. After the European Human Rights Court's rejection of Leyla Sahin's case, a medical student who wanted to continue her education wearing the headscarf although it is not legal to do so, MAZLUM-DER started not to appeal to the European Union on this issue, but continues to use the EU in its discourse on issues such as the military's role in Turkish politics. As for IHD, the organization is very supportive of the EU's approach to civil society in general, and of the harmonization process. As one representative argues, 'After 1999 both the clashes in the region and the pressure of the State on us have decreased. State started not to arrest us or not to take us into custody' (Diken 2006). The IHD's strength does not come from its appeal to the EU as a leverage tool, however. Rather, it is the EU's support of the IHD that puts pressure on the State.

\section{ABSTRACTS}

The boomerang and spiral models argue that domestic groups that are repressed by their states would seek international allies to help them affect their states' policies in favor of their own agenda. While these models explain the level of interconnectedness between domestic and international politics, and trace a framework that helps us study the transnational interactions between different actors, using "weak/strong" dichotomy to explain the domestic actors' position within the national realm prevents us from understanding the changing dynamics of state-domestic actor- international organization relations. Arguing that the perception of the international ally, that may change across time, and the levels of closeness of the domestic environment are factors that affect these relations, this paper focuses on three Turkish trade union confederations' appeal to the European Union since they started interacting with their 
European counterparts (since the 1960s). The research finds that the trade unions' using of the EU as a "stick" against the government depends on their own organizational position since their EU perceptions change according to the domestic environment.

INDEX

Mots-clés: transnational, relations UE-Turquie, modèle du boomerang, modèle de la spirale Keywords: transnational, boomerang model, spiral model, Turkey-European Union relations

\section{AUTHOR}

\section{ZEYNEP ALEMDAR}

Okan University, International Relations Department zalemo@uky.edu 